\section{Dental Pain: Is ATP the key mediator?}

\author{
Ernest A Jennings ${ }^{1,2,3 *}$ and Shenade J Bell ${ }^{1}$ \\ ${ }^{1}$ College of Medicine and Dentistry, James Cook University, Cairns, QLD, \\ Australia
}

${ }^{2}$ Centre for Biodiscovery and Molecular Development of Therapeutics, James Cook University, Cairns, QLD, Australia

${ }^{3}$ Australian Institute of Tropical Health and Medicine, James Cook University, Cairns, QLD, Australia

\begin{abstract}
Dental pain has a significant impact on the population and the mechanisms remain poorly understood. However, there is accumulating evidence that purinergic receptors are key contributors in central and peripheral dental nociception mechanisms. These purine receptors are localized in the trigeminal sensory neurons and are activated by Adenosine 5' Tri-Phosphate (ATP), which is thought to be a primary mediator in dental pain. Recent evidence has implicated purinergic receptors in persistent pain states. This includes increased sensitivity to ATP in satellite glia cells (which surround the trigeminal sensory neuron cell bodies), and reports of ATP signaling between dentin producing odontoblasts and trigeminal sensory neurons. This article will briefly summarize the importance of the purinergic receptor and ATP as a key mediator in the mechanisms of dental pain.

Dental pain has a significant impact on the population and presently its poorly described mechanisms limits its effective therapeutic management in patients. Purinergic receptors are accumulating interest as key contributors in central and peripheral dental nociception mechanisms. These receptors are localized in the trigeminal ganglia including dental pulp afferents and central afferent synapses.

Adenosine 5' Tri-Phosphate (ATP) is thought to be a primary mediator in dental pain, activating these purinergic receptors. Recent evidence has implicated purinergic receptors persistent stimulation in chronic pain states and increase of ATP nociception sensitivity in satellite glia cells located around trigeminal neuron cell bodies. Other emerging evidence has demonstrated ATP signaling in the dental pulp. Dentin producing odontoblasts release ATP and activate dental nociceptive afferents through the purinergic system. This article will briefly summarize the importance of the purinergic receptor and ATP as a key mediator in the mechanisms of dental pain.
\end{abstract}

*Corresponding author: Ernest A Jennings, College of Medicine and Dentistry, James Cook University, Cairns, QLD, Australia, Tel: +61 74232 1911, Fax: +61 740574588, E-mail: ernest.jennings@jcu.edu.au

Citation: Jennings EA, Bell SJ (2016) Dental Pain: Is ATP the key mediator? J Dent Oral Health Cosmesis 1: 004.

Received: March 01, 2016; Accepted: April 28, 2016; Published: May 13, 2016

\section{Introduction}

Dental pain has been shown to be prevalent in western society with reporting rates as high as $53 \%$ in random telephone surveys [1,2]. This pain has significant impact on daily function and is a major reason for presentation at dental clinics. Unfortunately, the underlying mechanisms of dental pain remain relatively poorly described.

Orofacial pain is conveyed centrally by trigeminal primary afferent fibres and most trigeminal nociceptive sensory neurons synapse in the trigeminal brainstem subnucleuscaudal is (also known as the medullary dorsal horn) before projecting to higher centers allowing conscious awareness and thus pain [3-5].

A key contributor to both peripheral and central components of trigeminal pain are purinergic receptors [6-9]. Adenosine 5' Tri-Phosphate (ATP) and related nucleotides act at both ionotropic (P2X) and metabotropic (P2Y) purinergic receptors and most P2X receptor subtypes, except for $\mathrm{P} 2 \mathrm{X}_{7}$, are expressed in the spinal dorsal horn neurons, dorsal root ganglia (DRG) and trigeminal ganglia, and the central terminals of primary afferents $[10,11]$. The aim of this article is to briefly summarize key evidence of the importance of purinergic receptor mechanisms in dental nociception (Figure 1).

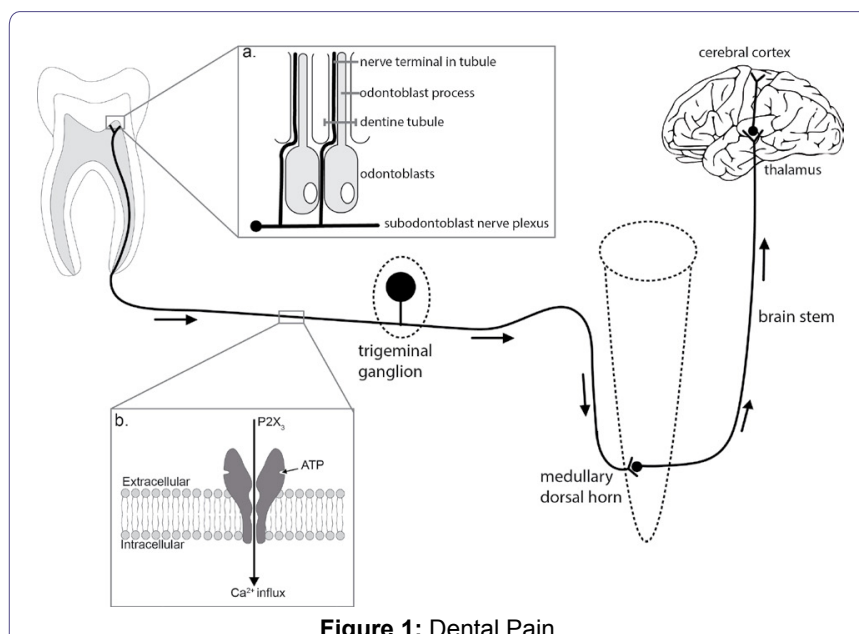

By definition, our perception of pain is dependent on cortical awareness. This schematic indicates the pathways involved. This review highlights the role of ATP signaling in three key peripheral areas. 1. Dental pulp and inset (a): schematic indicating the proximity of odontoblasts and trigeminal nerve terminals. Key data suggest that ATP released from odontoblasts binds to $\mathrm{P} 2 \mathrm{X}_{3}$ receptors thus lowering the activation threshold of these nerves. 2. Peripheral nerve fibres and trigeminal ganglia, including inset (b): Much cellular physiology and histology has focused on the trigeminal ganglion neurons, $\mathrm{P}_{2} \mathrm{X}_{3}$ receptors mediate a large $\mathrm{Ca}^{2+}$ flux which explains the profound impact that their activation has on cell excitation. 3. The trigeminal nociceptive sensory neurons terminate in the medullary dorsal horn (subnucleuscaudalis). Activation of P2X receptors at this synapse causes increases in excitatory neurotransmission.

There has been particular interest in $\mathrm{P}_{2} \mathrm{X}_{3}$ containing receptors in the trigeminal system as these receptors are found predominantly on small diameter nociceptive sensory neurons [12-17]. In addition, other key $\mathrm{P} 2 \mathrm{X}$ receptor subtypes that have attracted interest in the trigeminal system include $\mathrm{P} 2 \mathrm{X}_{1}, \mathrm{P} 2 \mathrm{X}_{2}$ and $\mathrm{P} 2 \mathrm{X}_{4}$ [14-17]. One 
functional reason for this interest is that many $\mathrm{P} 2 \mathrm{X}$ receptors mediate a large $\mathrm{Ca}^{2+}$ current, equivalent to that in the widely studied NMDA receptors [18].

Recent studies have raised the exciting possibility that satellite glia located around the trigeminal sensory neuron cell bodies may contribute actively to enhancing nociceptive transmission in this area. Both persistent inflammation and nerve damage induced a significant increase in the sensitivity of ATP applied to these cells [19]. The idea of neuron-glia cross talk in a similar inflammatory experiment implicated another ATP receptor, the $\mathrm{P}_{2} \mathrm{Y}_{2}$ receptor with compelling in vivo evidence that $\mathrm{P}_{2} \mathrm{Y}_{2}$ receptors may be a reasonable future drug target for persistent trigeminal inflammatory pain conditions [20] which may include many commonly seen dental pain conditions. This relatively new line of research is likely to yield significant results in the coming years.

ATP is known to act as a fast neurotransmitter at many central synapses [21]. Indeed, stimulation of $\mathrm{P}_{2} \mathrm{X}_{3}$ and containing receptors causes a significant increase in excitatory neurotransmission in the medullary dorsal horn [22]. In addition, stimulation of $\mathrm{P}_{2} \mathrm{X}_{3}$ and containing receptors in the tooth pulp is sufficient to induce central sensitization [12] thought to be a major contributor to chronic pain states $[5,23]$

What of the peripheral ends of the trigeminal sensory neurons that innervate teeth? We know that dentinal hypersensitivity may develop as a result of stimuli to exposed, sensitized, dentin following enamel loss through erosion and abrasion, attrition, dental caries and enamel or dental defects [24,25]. Trigeminal ganglion neurons and dental pulp nerve fibres project through the odontoblast layer and into the dentine tubules [26]. It has been shown that ATP is a key signaling molecule in this area. Not only have dentin producing odontoblasts been shown to release ATP $[25,27]$ but the enzymes necessary for extracellular ATP hydrolysis are also present in human dental pulp [28].

It is now well established that $\mathrm{P} 2 \mathrm{X}_{3}$ receptors are present on small diameter sensory nerve terminals in the dental pulp thus providing an appropriate target for ATP to interact with sensory nerves [7,26,29]. Considering the release of ATP, it has been established that a particular vesicular nucleotide transporter is responsible for packaging and releasing extracellular ATP [29] and this transporter is present in odontoblasts [30]. In addition, it was found that decreasing the amount of vesicular nucleotide transporter (using siRNA) resulted in a significant decrease in ATP release thus functionally implicating the transporter in this process [30].

The predominant theory relating to dentinal hypersensitivity is the hydrodynamic theory $[31,32]$. This theory suggests that mechanical stimuli be propagated along patent dentinal tubules and transduced within the pulp [32]. One important family of channels that sense mechanical and thermal stimuli are the TRP channels [33] and all of the odontoblast data reviewed above has involved either mechanical or thermal stimuli $[25,27,30]$.

ATP signaling has been implicated in mediating changes in mechanical sensitivity in other peripheral areas too. In the rodent hind limb, increases in extracellular ATP have been shown to contribute to mechanical allodynia [34]. Recently, chaperone proteins like sigma-1 receptors have been shown to facilitate the P2X receptor mediated mechanical allodynia [35] further contributing to understand the underlying mechanism behind ATP signaling in mechanical sensitivity. In trigeminal sensory neurons innervating the dura, it has been shown that ATP is released from a range of cell types including smooth muscles and endothelial cells [36], and that this ATP contributes to peripheral sensitization in trigeminal sensory neurons during migraine [14,36,37].

In conclusion, although we acknowledge that multiple mechanisms mediate dental pain we have shown that there is now strong evidence that ATP has a core role in dental and other pain states.

\section{References}

1. Locker D, Grushka M (1987) Prevalence of oral and facial pain and discomfort: preliminary results of a mail survey. Community Dent Oral Epidemiol 15: 169-172.

2. Macfarlane TV, Glenny AM, Worthington HV (2001) Systematic review of population-based epidemiological studies of oro-facial pain. J Dent 29: 451467.

3. Bereiter DA, Hirata H, Hu JW (2000) Trigeminal subnucleus caudalis: beyond homologies with the spinal dorsal horn. Pain 88: 221-224.

4. Sessle BJ (2000) Acute and chronic craniofacial pain: brainstem mechanisms of nociceptive transmission and neuroplasticity, and their clinical correlates. Crit Rev Oral Biol Med 11: 57-91.

5. Sessle BJ (2005) Trigeminal Central Sensitization. Reviews in Analgesia 8:85-102.

6. Khakh BS, North RA (2006) P2X receptors as cell-surface ATP sensors in health and disease. Nature 442: 527-532.

7. Lim JC, Mitchell CH (2012) Inflammation, pain, and pressure--purinergic signaling in oral tissues. J Dent Res 91: 1103-1109.

8. Nakatsuka T, Gu JG (2006) P2X purinoceptors and sensory transmission. Pflugers Arch 452: 598-607.

9. Salter MW (2004) Cellular neuroplasticity mechanisms mediating pain persistence. J Orofac Pain 18: 318-324.

10. Khakh BS (2001) Molecular physiology of P2X receptors and ATP signalling at synapses. Nat Rev Neurosci 2: 165-174.

11. North RA (2002) Molecular physiology of P2X receptors. Physiol Rev 82: 1013-1067.

12. Cherkas PS, Dostrovsky JO, Sessle BJ (2012) Activation of peripheral P2X receptors is sufficient to induce central sensitization in rat medullary dorsal horn nociceptive neurons. Neurosci Lett 526: 160-163.

13. Chung G, Jung SJ, Oh SB (2013) Cellular and molecular mechanisms of dental nociception. J Dent Res 92: 948-955.

14. Jennings $E A$, Cho $H$ (2007) Peripheral sensitisation in migraine - a role for purinergic P2X receptors in the dural-vascular pathway. Drug Development Research 68: 321-328.

15. Kim HY, Chung G, Jo HJ, Kim YS, Bae YC, et al. (2011) Characterization of dental nociceptive neurons. J Dent Res 90: 771-776.

16. Kuroda $H$, Shibukawa $Y$, Soya M, Masamura A, Kasahara M, et al. (2012) Expression of $\mathrm{P}_{2} \mathrm{X}_{1}$, and $\mathrm{P}_{2} \mathrm{X}_{4}$ receptors in rat trigeminal ganglion neurons. Neuroreport 23: 752-756.

17. Staikopoulos V, Sessle BJ, Furness JB, Jennings EA (2007) Localization of $\mathrm{P} 2 \mathrm{X} 2$ and $\mathrm{P} 2 \mathrm{X} 3$ receptors in rat trigeminal ganglion neurons. Neuroscience 144: 208-216.

18. Egan TM, Khakh BS (2004) Contribution of calcium ions to P2X channel responses. J Neurosci 24: 3413-3420.

19. Kushnir R, Cherkas P S, Hanani M (2011) Peripheral inflammation upregulates $\mathrm{P} 2 \mathrm{X}$ receptor expression in satellite glial cells of mouse trigeminal ganglia: A calcium imaging study. Neuropharmacology 61: 739-746. 
20. Magni G, Merli D, Verderio C, Abbracchio MP, Ceruti S et.al (2015) P2Y2 receptor antagonists as anti-allodynic agents in acute and sub-chronic trigeminal sensitization: Role of satellite glial cells. Glia 63:1256-1269.

21. Robertson SJ, Ennion SJ, Evans RJ, Edwards FA (2001) Synaptic P2X receptors. Curr Opin Neurobiol 11: 378-386.

22. Jennings EA, Christie MJ, Sessle BJ (2006) ATP potentiates neurotransmission in the rat trigeminal subnucleus caudalis. Neuroreport 17: 1507-1510.

23. Woolf CJ, Salter MW (2006) Plasticity and pain: role of the dorsal horn. In: Wall PD, McMahon SB, Koltzenburg M (eds.). Wall \& Melzack's Textbook of Pain (5thedn). Elsevier Churchill Linvingstone, Edinburgh, UK. Pg no: 91-105.

24. Chiang CY, Park SJ, Kwan CL, Hu JW, Sessle BJ (1998) NMDA receptor mechanisms contribute to neuroplasticity induced in caudalis nociceptive neurons by tooth pulp stimulation. J Neurophysiol 80: 2621-2631.

25. Shibukawa Y, Sato M, Kimura M, Sobhan U, Shimada M, et al. (2015) Odontoblasts as sensory receptors: transient receptor potential channels, pannexin-1, and ionotropic ATP receptors mediate intercellular odontoblast-neuron signal transduction. Pflugers Arch 467:843-863

26. Alavi AM, Dubyak GR, Burnstock G (2001) Immunohistochemical evidence for ATP receptors in human dental pulp. J Dent Res 80: 476-483.

27. Egbuniwe O, Grover S, Duggal AK, Mavroudis A, Yazdi M, et al. (2014) TRPA1 and TRPV4 activation in human odontoblasts stimulates ATP release. J Dent Res 93: 911-917.

28. Liu X, Yu L, Wang Q, Pelletier J, Fausther M, et al. (2012) Expression of ecto-ATPase NTPDase2 in human dental pulp. J Dent Res 91: 261-267.
29. Sawada K, Echigo N, Juge N, Miyaji T, Otsuka M, et al. (2008) Identification of a vesicular nucleotide transporter. Proc Natl Acad Sci USA 105: 5683-5686.

30. Ikeda E, Goto T, Gunjigake K, Kuroishi K, Ueda M, et al. (2016) Expression of Vesicular Nucleotide Transporter in Rat Odontoblasts. Acta Histochem Cytochem 49: 21-28.

31. Andrew D, Matthews B (2000) Displacement of the contents of dentinal tubules and sensory transduction in intradental nerves of the cat. J Physiol 3: 791-802.

32. West NX, Lussi A, Seong J, Hellwig E (2013) Dentin hypersensitivity: pain mechanisms and aetiology of exposed cervical dentin. Clin Oral Investig 17: 9-19.

33. Julius D (2013) TRP channels and pain. Annu Rev Cell Dev Biol 29: 355-384.

34. Seo HS, Roh DH, Yoon SY, Kang SY, Moon JY, et al. (2010) Peripheral acid-sensing ion channels and $\mathrm{P} 2 \mathrm{X}$ receptors contribute to mechanical allodynia in a rodent thrombus-induced ischemic pain model. J Pain 11: 718-727.

35. Kwon SG, Roh DH, Yoon SY, Choi SR, et al. (2016) Role of peripheral sigma-1 receptors in ischaemic pain: Potential interactions with ASIC and P2X receptors. Eur J Pain 20: 594-606.

36. Cieślak M, Czarnecka J, Roszek K, Komoszyński M (2015) The role of purinergic signaling in the etiology of migraine and novel antimigraine treatment. Purinergic Signal 11: 307-316.

37. Ferrari LF, Levine JD, Green PG3 (2016) Mechanisms mediating nitroglycerin-induced delayed-onset hyperalgesia in the rat. Neuroscience 317: 121 129. 